Open Access

\title{
Determinants of the competitiveness of smallholder African indigenous vegetable farmers in high-value agro-food chains in Kenya: A multivariate probit regression analysis
}

Evans Ngenoh ${ }^{1,3^{*}}$, Barnabas K. Kurgat ${ }^{2}$, Hillary K. Bett ${ }^{3}$, Sindu W. Kebede ${ }^{1}$ and Wolfgang Bokelmann ${ }^{1}$

\author{
*Correspondence: ken.ngenoh@ \\ gmail.com \\ 'Department of Agricultural \\ Economics, Humboldt University of \\ Berlin, Invalidenstr. 42, 10115 Berlin, \\ Germany \\ ${ }^{3}$ Department of Agricultural \\ Economics and Agribusiness \\ Management, Egerton University, \\ P.O. Box 536, Egerton 20115, Kenya \\ Full list of author information is \\ available at the end of the article
}

\begin{abstract}
Smallholder farmers are excluded from efficient and effective participation in high-value agro-food market chains due to major competitiveness constraints and several market failures along these chains. The purpose of this study is to contribute to the competitiveness of smallholder farmers in a more coordinated and sustainable way that promote their effective and efficient participation in high-value agro-food market chains. In particular, the study aims at determining the main role of households' capitals, institutional, and access-related factors in conditioning the decision of smallholder farmers of African indigenous vegetables (AlVs) to access pillars of competitiveness in high-value market chains (HVMCs). For this purpose, a unique household-level data from a total of 1232 rural and peri-urban AIV-producing households were surveyed, and the data obtained were analysed by using a multivariate probit model.

The results suggest that about two thirds of smallholder Alv farmers had access to at least one pillar of competitiveness in HVMCs. The model results show the presence of interdependency of household level decisions to access multiple pillars of competitiveness in HVMCs. Furthermore, the results also reveal that coping with shocks, coupled with access to information on market prices and warnings of unexpected events, contract farming, certification and modern irrigation technologies are the main conditioning factors to the access of the pillars of competitiveness by smallholder farmers.

The promotion and implementation of a well-founded mobile phone-based information access platforms, as well as effective and efficient livelihood strategies that support smallholder farmers to access pillars of competitiveness, is of critical importance towards overcoming the major competitiveness constraints along high-value agro-food chains.
\end{abstract}

\section{Introduction}

The agriculture sector is vital to the economy of many developing countries because it provides raw materials, food and employment to the rising and urbanising population, thus improving the welfare of producers who are poor smallholder farmers (Rios et al. 2008; Zuwarimwe and Mbaai 2015; von Grebmer et al. 2016). Furthermore, its role in improving the livelihoods of smallholder farmers has remained the major strategy towards sustainable rural development through effective and efficient forward and

(c) The Author(s). 2019 Open Access This article is distributed under the terms of the Creative Commons Attribution 4.0 International License (http://creativecommons.org/licenses/by/4.0/), which permits unrestricted use, distribution, and reproduction in any medium, provided you give appropriate credit to the original author(s) and the source, provide a link to the Creative Commons license, and indicate if changes were made. 
backward linkages (Olwande et al. 2015). Currently, most developing countries are struggling to secure an adequate and nutritious food supply to match rising demand through various strategies of increasing agricultural production capacity and enhancing the commercialisation of farm produce (Muhanji et al. 2011; FAO 2014; Zuwarimwe and Mbaai 2015). This is due to the strong link between the strategic direction taken by smallholder farmers when organising their scarce resources and the market conditions for the produce, along with other investments and innovations.

Market-oriented production in Sub-Saharan Africa (SSA) can play a significant role in the households of smallholder farmers if sustainable market integration is embraced (Xinshen et al. 2007). Many African countries have therefore introduced policies and programmes to support the integration of smallholder farmers in input and output markets through agricultural intensification and commercialisation (Barrett 2008) since the competitiveness ${ }^{1}$ of smallholder farmers in most markets in SSA is still low, despite agriculture's significant contribution to household food security and poverty alleviation (Barrett 2008; Omiti et al. 2009; Olwande et al. 2015). Furthermore, linking smallholder farmers to markets reduces the cost of agricultural products and strengthens the economic linkages between farm and non-farm production systems (Fischer and Qaim 2012; Rao et al. 2012).

As a developing country, Kenya is currently facing both social and environmental challenges, with the main problem being poverty (FAO 2014). This has led to the country suffering from transitory and chronic food insecurity, which has been associated with a numbers of factors such as agricultural production and marketing shocks (PMS), a growing population, low market-oriented production, poor institutional and infrastructural development, and a heavy reliance on rain-fed agriculture (Ngugi et al. 2007; Omiti 2012). Recently, the emergence of high-value market chains ${ }^{2}$ (HVMCs) has triggered the commercialisation of African indigenous vegetables (AIVs) and other farm products (Reardon et al. 2009; Chelang'a et al. 2013). This has made policymakers aware of the importance of AIVs in terms of their role in improving the food situation, nutritional status, income and health of rural and urban households alike in Kenya (Ngugi et al. 2007). The enactment of the Kenyan food security and nutrition policy in the development blue print entitled Vision 2030 was solely informed by these developments, with the main aim of ensuring food and nutritional security in all parts of the country at all times (Omiti 2012; Ngenoh et al. 2016). This is due to the fact that these vegetables have medicinal properties (Kimiywe et al. 2007; Chege et al. 2014), are highly nutritious (Mampholo et al. 2016) and have great potential to attract a premium of up to $79 \%$ in urban retail outlets in Kenya under the conditions of consistent supply and packaging (Muhanji et al. 2011; Chelang'a et al. 2013). Furthermore, the majority of rural and urban households rely on these vegetables to fulfil their daily food and nutritional requirements for micronutrients, particularly vitamin A and iron (Chadha, 2006).

The production, handling and marketing of AIVs are mostly performed by smallholder farmers in Kenya (Ngugi et al. 2007; Omiti 2012; Ngenoh et al. 2016), and this puts AIVs in a central position as a catalyst for rural development. Consequently, AIV production provides an economic pillar for the livelihood of rural smallholder farmers and therefore represents a livelihood strategy whose implementation should continuously be targeted through sustainable means. According to Schippers (2000), AIVs play a crucial role in income generation and subsistence for the very poorest and thus help 
them earn a living as producers and traders without substantial capital investment being required. Additionally, the area under AIV cultivation in Kenya increased from 27,102 ha in 2009 to 35,503 ha in 2014, while their yields and value rose by $6 \%$ and $10 \%$ respectively between 2012 and 2014 (HCDA 2014). Currently, the demand for AIVs has been increasing in major marketing outlets (formal and informal markets) in urban centres in Kenya (Ngugi et al. 2007; Fischer and Qaim 2012; Chelang'a et al. 2013; Ngenoh et al. 2016). Despite this great potential, there is inconsistency in the supply of these vegetables to the majority of HVMCs across urban areas of the country (Ngugi et al. 2007; Chelang'a et al. 2013). Therefore, for smallholder AIV farmers to meet and benefit from this rising demand, they should be integrated into HVMCs so as to sustainably produce and supply vegetables all year round (Ngugi et al. 2007). However, recent studies have indicated that the majority of smallholder farmers are being excluded from the significant growth opportunities offered by HVMCs (Fernandez-Stark et al. 2012; Omiti 2012; Chelang'a et al. 2013) since they face numerous competitiveness bottlenecks (Fig. 1) and market failures along these chains such as low productivity, poor product quality, lack of standards compliance, high transaction costs and a lack of networks among others (Narrod et al. 2009; Rao et al. 2012; Boström et al. 2015). These challenges have further reduced their sustainable entry into HVMCs, and hence, there is a need for a holistic approach to address these constraints in a more coordinated and sustainable way that promotes their effective participation in such lucrative high-value agro-food market chains (Fernandez-Stark et al. 2012). This has been aggravated by stringent regulations in terms of consumer demands from HVMCs, coupled with their sophistication and consolidation, which have made it more difficult for smallholder farmers to participate in these chains (Fernandez-Stark et al. 2012; Rao et al. 2012).

To overcome these challenges, Fernandez-Stark et al. (2012) have proposed a four-pillar ${ }^{3}$ model for holistically enhancing the competitiveness of smallholder farmers in HVMCs. The inclusion of smallholder farmers in HVMCs involves significant changes that require them to holistically overcome the major competitiveness constraints and numerous market failures that limit their competitiveness and thus their sustainable entry into these chains. The authors argue that access to these four pillars

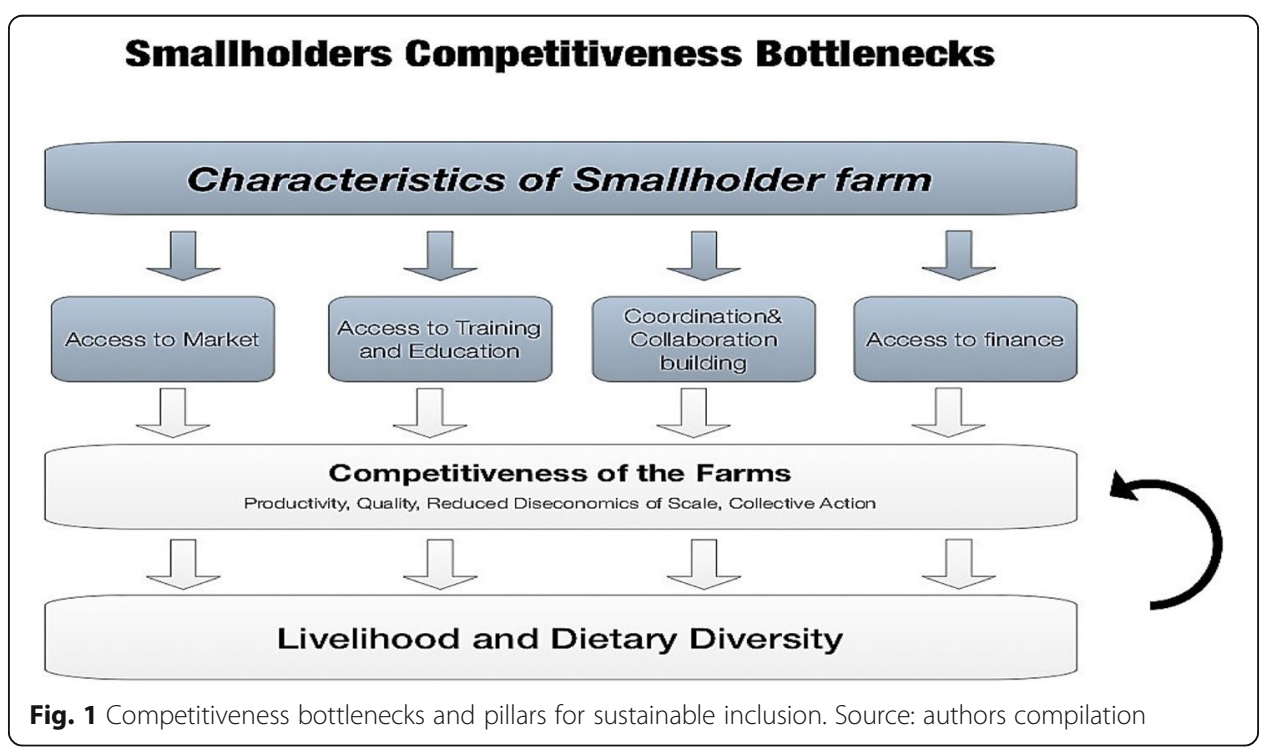


by smallholder farmers will lead to several complementary and integrated investments that will ultimately translate competitiveness constraints into income opportunities and serve as a means of reducing poverty. Against this backdrop, this study sought to contribute to the understanding of how smallholder AIV farmers can be supported effectively and efficiently to ensure that they are included in HVMCs in a sustainable way. This will only be possible if they receive assistance with overcoming the significant competitiveness challenges and bottlenecks that prevent them from accessing HVMCs. Therefore, identifying the drivers and incentives for accessing high-value markets, training/extension, finance/credit and farmers' groups may improve smallholder AIV farmers' chances of competing successfully and sustainably in HVMCs. Finally, it will also provide a clear framework that could be used by policymakers when making decisions about how to support this vulnerable group of farmers so that vibrant agro-food HVMCs can be developed which, in turn, will improve rural household food security and reduce poverty.

The reviews conducted for this paper show that previous studies (Markelova et al. 2009; Narrod et al. 2009; Gruère et al. 2009; Fischer and Qaim 2012; Trebbin 2014; Ma and Abdulai 2016) have only used collective action/farmers' groups to link farmers to the markets on the assumption that these are the best model for farmers to access other pre-conditioning factors, without considering the heterogeneity of smallholder farmers in terms of their household characteristics and resources. Additionally, Ferris et al. (2014) used the involvement of extension services and advisory services in linking smallholder farmers with niche markets. Therefore, this paper's contribution is twofold. First, using a "holistic" model with four key pillars or intervention instruments (access to HVMCs, credit services, extension services and farmers' groups), it was possible to identify the main drivers and incentives for overcoming the major constraints limiting the competitiveness of smallholder AIV farmers in HVMCs. Second, using a multivariate probit model, it was possible to estimate the influence of exogenous factors on simultaneous decisions about accessing the four key pillars of competitiveness, while allowing for the error terms of each of these pillars to be freely correlated. Furthermore, the model allowed the complementarities and substitutabilities of these pillars of competitiveness to be captured and hence their promotion to be facilitated in order to achieve the maximum welfare benefit for smallholder AIV farmers.

\section{Data and descriptive statistics}

The comprehensive cross-sectional data used in this analysis were derived from the Horticultural Innovation and Learning for Improved Nutrition and Livelihood in East Africa (HORTINLEA) project survey conducted in 2014. The project focused on five types of AIVs: African nightshade (Solanum scabrum), spider plant (Cleome gynandra), amaranth (Amaranthus spp), cowpea (Vigna unguiculata) and Ethiopian kale (Brassica carinata). The survey used a multistage sampling technique to collect data from a total sample of 1232 AIV-producing households, comprising 806 from rural counties and 426 from peri-urban counties. Smallholder farmers from Kisii and Kakamega counties represented rural areas, while those from Nakuru, Kiambu and Kajiado counties represented peri-urban areas. These counties were selected based on statistics from the Ministry of Agriculture on the relevance and intensity of the production and marketing of AIVs (Government of Kenya (GoK) 2012). At village level, smallholder AIV farming 
households were randomly selected, including those that had accessed HVMC pillars ${ }^{4}$ of competitiveness and those that had not. The information on household and farm-level characteristics, production and marketing activities, and institutional and access-related variables were collected from respondents using a structured and pre-tested questionnaire. The independent variables included in the estimation were chosen based on a review of previous studies (Man et al. 2002; Ajitabh and Momaya 2004; Markelova et al. 2009; Narrod et al. 2009; Gruère et al. 2009; Fernandez-Stark et al. 2012; Fischer and Qaim 2012; Trebbin 2014; Ma and Abdulai 2016).

The description and summary statistics of the variables used in this study are presented in Table 1. Respondents were asked whether they had access to any of the four key pillars of competitiveness in HVMC during the 2013/2014 production and marketing season. Since different modes of access to market channels, chains or outlets were observed, a differentiation was made between conventional (normal) market channels and HVMCs. It was specifically noted that $72.1 \%$ of farmers were selling their vegetables to different channels. Furthermore, $51.7 \%$ and $20.4 \%$ of these farmers sold their vegetables to conventional market chains and HVMCs respectively. Therefore, a comparison was made between farmers who had access to HVMCs and those who did not (those who sold to conventional channels and those who did not sell at all).

Furthermore, with regards to other competitiveness pillars, $36.8 \%$ of smallholder AIV farmers were found to have access to farmers' groups, $37.1 \%$ had access to extension services, while $19.3 \%$ accessed credit services (Table 1). Moreover, the findings indicated that the majority (65\%) of AIV farmers were from rural areas and were predominantly (81\%) headed by males with an average age of 49.8 years and an education level of 9.4 years. The average household size was between five and six members, with the majority of their household heads $(80 \%)$ being married. The average land size was 0.92 acres, with $89 \%$ of households owning their parcels of land. About $16 \%$ of AIV households used modern irrigation systems, indicating a low level of production technology.

\section{Theoretical framework}

This study was based on a theoretical framework (a four-pillar or holistic model) for the inclusion of smallholder farmers in high-value agro-food chains, which was proposed by Fernandez-Stark et al. (2012). It draws on the concept of competitiveness at farm level. They argue that smallholder farmers should become competitive in order to participate in HVMCs. However, the potential involvement of smallholder farmers in HVMCs presents a challenge because they usually face competitiveness bottlenecks such as low productivity, poor product quality, lack of compliance with standards, high transaction costs and a lack of networks. These competitiveness bottlenecks are difficult for smallholders to overcome because they face numerous constraints. These constraints include a lack of access to markets, training (technical, interpersonal and entrepreneurial skills), collaborative networks (among small producers and with chain stakeholders) and finance. Consequently, the authors of this model highlight that if smallholders' farmers were relieved of these constraints, they would have the opportunity to become competitive and effectively participate in HVMCs in a sustainable manner. In particular, the holistic model considers four key "pillars"-access to markets, access to training, collaboration and cooperation building, and access to finance-as intervention instruments for overcoming competitiveness constraints and thus 
Table 1 Description and summary statistics of selected variables

\begin{tabular}{|c|c|c|c|}
\hline Variables & Description & Mean & $\begin{array}{l}\text { Std. } \\
\text { Dev. }\end{array}$ \\
\hline \multicolumn{4}{|l|}{ Dependent variables } \\
\hline $\begin{array}{l}\text { Access to high-value } \\
\text { markets }\end{array}$ & $\begin{array}{l}1 \text { if household has access to high-value AIV markets, } 0 \\
\text { otherwise }\end{array}$ & 0.20 & 0.403 \\
\hline $\begin{array}{l}\text { Membership to farmers' } \\
\text { groups }\end{array}$ & $\begin{array}{l}1 \text { if household head/spouse are members of a farmers' group, } \\
0 \text { otherwise }\end{array}$ & 0.37 & 0.482 \\
\hline Access to credit services & 1 if household has access to credit services, 0 otherwise & 0.19 & 0.395 \\
\hline $\begin{array}{l}\text { Access to extension } \\
\text { services }\end{array}$ & $\begin{array}{l}1 \text { if household has access to extension/training services, } \\
0 \text { otherwise }\end{array}$ & 0.37 & 0.483 \\
\hline \multicolumn{4}{|l|}{ Independent variables } \\
\hline Household size & Total number of household/family members & 5.62 & 2.283 \\
\hline Gender & 1 if gender of household head is male, 0 otherwise & 0.81 & 0.396 \\
\hline Age & Age of household head in years & 49.76 & 12.632 \\
\hline Marital status & 1 if household head is married, 0 otherwise & 0.80 & 0.399 \\
\hline Education & Years of education of the household head & 9.44 & 4.605 \\
\hline Land tenure & 1 if farm is owned, 0 otherwise & 0.89 & 0.315 \\
\hline Coping with PMS & $\begin{array}{l}1 \text { if household copes with production and marketing shocks, } 0 \\
\text { otherwise }\end{array}$ & 0.79 & 0.422 \\
\hline Farm location & 1 if farm is in rural area, 0 otherwise & 0.65 & 0.476 \\
\hline Land size & Total size of land owned by the household in acres & 0.92 & 2.044 \\
\hline AlV intensification & $\begin{array}{l}\text { Proportion of AIV land area to total household land size fully } \\
\text { owned }\end{array}$ & 0.35 & 0.256 \\
\hline Fertile soil & 1 if farm is very fertile, 0 otherwise & 0.55 & 0.498 \\
\hline Distance to watering point & Total distance to the nearest main water source in kilometres & 0.35 & 2.127 \\
\hline Distance to market & Total distance to the nearest markets in kilometres & 2.38 & 2.517 \\
\hline Distance to agro-vet & Total distance to the nearest agro-vet in kilometres & 2.17 & 3.572 \\
\hline Type of irrigation system & 1 if household uses modern irrigation system, 0 otherwise & 0.16 & 0.367 \\
\hline TLU* & Total household livestock units & 0.76 & 0.574 \\
\hline $\begin{array}{l}\text { Number of farm } \\
\text { enterprises }\end{array}$ & Total number of farm enterprises in a household & 5.57 & 2.276 \\
\hline Grading of AIV & 1 if household grades Alvs before selling, 0 otherwise & 0.37 & 0.482 \\
\hline Off-farm income & 1 if household has access to off-farm income, 0 otherwise & 0.29 & 0.454 \\
\hline Access to information & $\begin{array}{l}1 \text { if household has access to AIV market information, } 0 \\
\text { otherwise }\end{array}$ & 0.37 & 0.484 \\
\hline $\begin{array}{l}\text { Access to warning on } \\
\text { shocks }\end{array}$ & $\begin{array}{l}1 \text { if household has access to warnings about shocks, } 0 \\
\text { otherwise }\end{array}$ & 0.16 & 0.367 \\
\hline Contract farming & 1 if household has access to contract farming, 0 otherwise & 0.08 & 0.268 \\
\hline Certification & 1 if household is a certified AlV producer, 0 otherwise & 0.28 & 0.452 \\
\hline
\end{tabular}

${ }^{*}$ Total livestock units as defined in Jahnke (1982)

improving smallholder farmers' competitiveness and sustaining their inclusion in HVMCs. For instance, access to these intervention instruments by smallholder farmers can enable them to overcome productivity-related challenges such as a lack of exposure to buyers (HVMCs) and their requirements, a lack of technical and entrepreneurial skills, a lack of information flow with other producers and also other actors in the chain, and a lack of access to finance to buy equipment, infrastructure or necessary inputs. ${ }^{5}$

There are many theoretical frameworks for competitiveness at farm level that includes, for instance, those developed by Buckley et al. (1992), Man et al. (2002) and 
Ajitabh and Momaya (2004) among others. Buckley et al. (1992) conceptualised a model for a farm's competitiveness that contains three interrelated dimensions (performance, potential and process). Ajitabh and Momaya (2004) meanwhile focused on the main competitiveness sources at a company level using an asset-processesperformance (APP) framework. Man et al. (2002) developed a theoretical framework for the competitiveness of small and medium-sized enterprises (SME) by drawing on the concept of competitiveness at farm level. However, they focused mainly on the key determinants of competitiveness and considered the dimensions (assets, potential, process, performance) of a farm's competitiveness alongside four attributes (long-term orientation, controllability, relativity and dynamism). However, the holistic model is superior when compared to other competitiveness models because it focuses specifically on potential pathways for the inclusion of smallholder farmers in HVMCs. They suggest that in order for smallholder farmers to achieve long-term competitiveness, there is a need to effectively exploit the available opportunities for improving competitiveness-enhancing factors, such as building up their household capitals/assets and resources, as well as efficient and effective utilisation of their institutional connections. Therefore, the holistic model of Fernandez-Stark et al. (2012) was used in this study to assess the determinants of competitiveness of smallholder African indigenous vegetable farmers in high-value agro-food chains in Kenya. The reason for this is that access to markets and critical services such as training and finance, as well as strong and effective collaboration and cooperation, will provide opportunities for smallholder AIV farmers to become competitive on a lasting basis.

\section{Empirical specifications}

\section{Conceptual framework}

The conceptual framework employed in this study was based on the assumption that AIV farmers choose to access pillars of competitiveness or not because they are assumed to be risk neutral. Furthermore, smallholder AIV farmers take into account the expected net returns $\left(P_{N R A}^{*}\right)$ derived from AIV production by accessing pillars of competitiveness and the expected net returns $\left(P_{N R}^{*}\right)$ derived by not accessing these pillars. Smallholder AIV farming households will decide to access to pillars of competitiveness if the perceived utility or net returns from access $\left(P_{N R A}^{*}\right)$ is significantly greater than is the case without it $\left(P_{N R}^{*}\right)$. Although utility is not directly observed, the actions of smallholder AIV farmers are observed through the choices they make, for instance, they would choose to access pillars of competitiveness if $P_{i}^{*}>0$. Therefore, $P_{i}^{*}$ can be expressed as a function of observable elements in the following latent variable model:

$$
P_{i}^{*}=\beta X_{i}+\mu_{i}, P_{i}=1 \text { if } P_{i}^{*}>0
$$

where $P_{i}$ is a binary indicator variable that equals 1 for household $i$ that has accessed pillars of competitiveness, and 0 otherwise; $X_{i}$ is a set of explanatory variables; $\beta$ represents the parameters to be estimated; and $\mu_{i}$ is an error term assumed to be normally distributed with zero mean. The probability of smallholder AIV farmers adopting SIPs can be expressed as:

$$
\operatorname{Pr}\left(P_{i}=1\right)=\operatorname{Pr}\left(P_{i}^{*}>0\right)=\operatorname{Pr}\left(\mu_{i}>-\beta X_{i}\right)=1-F\left(-\beta X_{i}\right)
$$

where $F$ is the cumulative distribution function for $\mu_{i}$. 


\section{Multivariate probit model}

In this study, smallholder AIV farmers' decisions to select pillars of competitiveness involved multiple choices and they would therefore be expected to choose a combination of pillars rather than just selecting one. It was therefore necessary to use a model that estimates the influence of exogenous variables on simultaneous decisions of accessing various pillars of competitiveness, while allowing for the error terms of each of these pillars to be freely correlated. Therefore, in this study, a multivariate probit (MVP) model was used, which is appropriate for estimating the influence of exogenous factors on smallholder AIV farmers' decisions to access pillars of competitiveness in HVMCs, while allowing the correlation of error terms of different decisions equations (Maddala 1986; Wooldridge 2010). Furthermore, the model enables the complementarities and substitutabilities of these pillars of competitiveness to be captured and hence enhances the strategies used in the promotion of their access among smallholder farmers for maximum welfare benefit. Therefore, following the recommendation of Maddala (1986) and Wooldridge (2010), a typical empirical specification for the MVP model is characterised by a set of binary dependent variables $\left(P_{\text {in }}\right)$ such that:

$$
P_{i n}^{*}=\beta_{n}^{\prime} X_{i}+u_{i n}, n=1, \ldots ., 4
$$

and

$$
P_{\text {in }}=\left\{\begin{array}{l}
1 \text { if } P_{\text {in }}^{*}>0 \\
0 \text { otherwise }
\end{array}\right.
$$

where $\beta_{n}^{\prime}$ is the corresponding vector of parameters to be estimated and $P_{i n}^{*}$ is the latent variable. Each of the equations was considered using the same set of independent variables $\left(X_{i p n}\right)$ described in Table 1.

\section{Results and discussion}

\section{Pairwise correlations}

The multivariate probit regression model was estimated at household level. The results from the pairwise correlation are presented in Table 2.

These results show a likelihood ratio test of $\chi^{2}(6)=13.416(p<0.013)$, which suggests the presence of interdependence between multiple pillars of competitiveness in HVMC. These results supported the use of the multivariate probit model to analyse the determinants of access to pillars of competitiveness in HVMC among smallholder AIV farmers. Furthermore, the findings suggested that some of the pillars of competitiveness in HVMC were complements, with four out of six correlation coefficients being

Table 2 Correlation coefficients of pillars of competitiveness in HVMC from MVP estimation

\begin{tabular}{lll}
\hline HVMC competitiveness pillars & Correlation coefficient & Standard error \\
\hline High-value market and membership of farmers' group & -0.0232 & 0.0548 \\
Credit services and high-value market & $0.1092^{* *}$ & 0.0579 \\
Extension services and high-value market & -0.0612 & 0.0525 \\
Credit services and membership of a farmers' group & $0.0901^{* *}$ & 0.0530 \\
Extension services and membership of farmers' group & $0.0927^{* *}$ & 0.0467 \\
Extension services and credit services & $0.1062^{* *}$ & 0.0499 \\
\hline
\end{tabular}

Likelihood ratio test of $r h o 21=\operatorname{rho} 31=\operatorname{rho} 41=\operatorname{rho} 32=\operatorname{rho} 42=\operatorname{rho} 43=0 ; X^{2}(6)=13.416$ Prob $>X^{2}=0.013$ ${ }^{* *} p<0.05$ 
statistically significant, indicating that access to the pillars of competitiveness in HVMC among smallholder AIV farmers was not mutually independent.

\section{Determinants of the choice of pillars of competitiveness in HVMCs}

The results of the parameter estimates from the multivariate probit model suggest that capital endowments and entitlements, institutions and access-related variables at household level were significant in informing decisions to access pillars of competitiveness in HVMCs (Table 3). Social capital variables were the main determinants of smallholder farmers' access to pillars of competitiveness in HVMCs. Coping with PMS was used as a dummy variable representing households that responded to productions shocks (drought, floods, pest and diseases, crop failure, among other production-related shocks) and those that responded to marketing shocks (food, input and output prices). The results of this study were consistent with other studies (Frankenberger et al. 2013; Franken et al. 2014) in that smallholder AIV farmers who managed to respond to PMS were found to be more likely to access the EXT and CRD competitiveness pillars. Depending on the type of shock and the household's ability/capacity, as well as the opportunity cost, to not respond to shocks, smallholder AIV farmers who are risk-averse were more likely to avoid spot markets and engage in forward contracts due to their ability to enhance the transformative capacity of reducing market transaction costs. This is only possible if smallholder farmers have access to relevant and appropriate information, as well as the necessary resources that can enhance their adaptive capacity.

Access to HVMC for risk reduction through market-oriented production is a powerful risk mitigation strategy that can enable smallholder farmers to diversify away from spot markets with high price volatilities (Barrett 2008; Torero 2011). Therefore, for smallholder farmers to participate in HVMC effectively and efficiently, there is a need for them to explore appropriate opportunities for enhancing their asset base and overcoming market constraints and poverty. In general, HVMC activities demand greater assets, liquidity and credit from smallholder farmers and require greater risk mitigation, all of which requires them to access pillars of competitiveness in HVMCs in order to bear the effects of production and marketing shocks and alleviate transaction costs. In line with Barrett et al. (2001), smallholder households who own their land were also found to have a negative relationship with access to the CRD competitiveness pillar. This implies that smallholder AIV farmers who fully own their farmland are less likely to access credit services, which is largely attributed to the fact that most of them, especially in rural areas, have limited access to formal credit providers who can help them gain access to unexploitative credit, despite them having the necessary collateral to access formal credit services. This is due to there being a limited number or even total absence of formal credit providers in most rural areas in Kenya (Kiplimo et al. 2015).

With regard to institutional and access-related factors, access to market information (prices) was found to have positive effects on the EXT and CRD competitiveness pillars. This implies that smallholder AIV farmers who have access to relevant and appropriate price information, especially for inputs and outputs, are more likely to access extension and credit services. In addition, smallholder farmers who have access to information about the price of agricultural products that are harvested from their farms are more likely to seek extension services, especially with regard to how to preserve/store their 
Table 3 Parameter estimates from multivariate probit and individual probit models for estimating determinants of pillars of competitiveness in HVMC

\begin{tabular}{|c|c|c|c|c|c|c|c|c|}
\hline \multirow[t]{2}{*}{ Variable } & \multicolumn{4}{|c|}{ Multivariate probit estimates } & \multicolumn{4}{|c|}{ Individual probit estimates } \\
\hline & HVM & GRP & CRD & EXT & HVM & GRP & CRD & EXT \\
\hline $\begin{array}{l}\text { Household } \\
\text { size }\end{array}$ & $\begin{array}{l}0.0130 \\
(0.0213)\end{array}$ & $\begin{array}{l}-0.0083 \\
(0.0189)\end{array}$ & $\begin{array}{l}0.0348^{*} \\
(0.0207)\end{array}$ & $\begin{array}{l}0.0243 \\
(0.0186)\end{array}$ & $\begin{array}{l}0.0008 \\
(0.0052)\end{array}$ & $\begin{array}{l}-0.0030 \\
(0.0061)\end{array}$ & $\begin{array}{l}0.0088^{*} \\
(0.0054)\end{array}$ & $\begin{array}{l}0.0079 \\
(0.0064)\end{array}$ \\
\hline Gender & $\begin{array}{l}-0.1936 \\
(0.1597)\end{array}$ & $\begin{array}{l}0.1548 \\
(0.1488)\end{array}$ & $\begin{array}{l}-0.0653 \\
(0.1636)\end{array}$ & $\begin{array}{l}-0.0069 \\
(0.1414)\end{array}$ & $\begin{array}{l}-0.0425 \\
(0.0400)\end{array}$ & $\begin{array}{l}0.0424 \\
(0.0463)\end{array}$ & $\begin{array}{l}-0.0219 \\
(0.0409)\end{array}$ & $\begin{array}{l}-0.0056 \\
(0.0485)\end{array}$ \\
\hline Age & $\begin{array}{l}0.0006 \\
(0.0036)\end{array}$ & $\begin{array}{l}0.0007 \\
(0.0033)\end{array}$ & $\begin{array}{l}0.0004 \\
(0.0037)\end{array}$ & $\begin{array}{l}-0.0001 \\
(0.0033)\end{array}$ & $\begin{array}{l}0.0001 \\
(0.0009)\end{array}$ & $\begin{array}{l}0.0001 \\
(0.0010)\end{array}$ & $\begin{array}{l}0.0004 \\
(0.0009)\end{array}$ & $\begin{array}{l}-0.0001 \\
(0.0011)\end{array}$ \\
\hline Marital status & $\begin{array}{l}0.2254 \\
(0.1611)\end{array}$ & $\begin{array}{l}0.0686 \\
(0.1476)\end{array}$ & $\begin{array}{l}0.0324 \\
(0.1635)\end{array}$ & $\begin{array}{l}-0.0021 \\
(0.1407)\end{array}$ & $\begin{array}{l}0.0483 \\
(0.0396)\end{array}$ & $\begin{array}{l}0.0275 \\
(0.0459)\end{array}$ & $\begin{array}{l}0.0054 \\
(0.0405)\end{array}$ & $\begin{array}{l}-0.0010 \\
(0.0481)\end{array}$ \\
\hline Education & $\begin{array}{l}-0.0066 \\
(0.0103)\end{array}$ & $\begin{array}{l}0.0003 \\
(0.0096)\end{array}$ & $\begin{array}{l}0.0421^{* * *} \\
(0.0104)\end{array}$ & $\begin{array}{l}0.0229^{* *} \\
(0.0092)\end{array}$ & $\begin{array}{l}-0.0018 \\
(0.0026)\end{array}$ & $\begin{array}{l}0.0008 \\
(0.0030)\end{array}$ & $\begin{array}{l}0.0106^{* * *} \\
(0.0027)\end{array}$ & $\begin{array}{l}0.0077^{* *} \\
(0.0032)\end{array}$ \\
\hline Land tenure & $\begin{array}{l}0.1614 \\
(0.1490)\end{array}$ & $\begin{array}{l}0.1001 \\
(0.1269)\end{array}$ & $\begin{array}{l}-0.2925^{* *} \\
(0.1298)\end{array}$ & $\begin{array}{l}0.0365 \\
(0.1221)\end{array}$ & $\begin{array}{l}0.0346 \\
(0.0347)\end{array}$ & $\begin{array}{l}0.0306 \\
(0.0401)\end{array}$ & $\begin{array}{l}-0.0847^{* *} \\
(0.0355)\end{array}$ & $\begin{array}{l}0.0115 \\
(0.0420)\end{array}$ \\
\hline $\begin{array}{l}\text { Coping with } \\
\text { PMS }\end{array}$ & $\begin{array}{l}0.0023 \\
(0.0940)\end{array}$ & $\begin{array}{l}0.0424 \\
(0.0846)\end{array}$ & $\begin{array}{l}0.2747^{* * *} \\
(0.0924)\end{array}$ & $\begin{array}{l}0.1446^{*} \\
(0.0818)\end{array}$ & $\begin{array}{l}0.0064 \\
(0.0233)\end{array}$ & $\begin{array}{l}0.0129 \\
(0.0269)\end{array}$ & $\begin{array}{l}0.0748^{* * *} \\
(0.0238)\end{array}$ & $\begin{array}{l}0.0486^{*} \\
(0.0282)\end{array}$ \\
\hline Farm location & $\begin{array}{l}-1.0216^{* * *} \\
(0.1204)\end{array}$ & $\begin{array}{l}1.3580^{* * *} \\
(0.1262)\end{array}$ & $\begin{array}{l}-0.3731^{* * *} \\
(0.1191)\end{array}$ & $\begin{array}{l}0.3816^{* * *} \\
(0.1125)\end{array}$ & $\begin{array}{l}-0.2779^{* * *} \\
(0.0307)\end{array}$ & $\begin{array}{l}0.4045^{* * *} \\
(0.0356)\end{array}$ & $\begin{array}{l}-0.1011^{* * *} \\
(0.0314)\end{array}$ & $\begin{array}{l}0.1202^{* * *} \\
(0.0372)\end{array}$ \\
\hline Land size & $\begin{array}{l}-0.0029 \\
(0.0222)\end{array}$ & $\begin{array}{l}0.0224 \\
(0.0246)\end{array}$ & $\begin{array}{l}0.0052 \\
(0.0184)\end{array}$ & $\begin{array}{l}0.0246 \\
(0.0194)\end{array}$ & $\begin{array}{l}-0.0008 \\
(0.0053)\end{array}$ & $\begin{array}{l}-0.0052 \\
(0.0062)\end{array}$ & $\begin{array}{l}0.0018 \\
(0.0055)\end{array}$ & $\begin{array}{l}0.0079 \\
(0.0065)\end{array}$ \\
\hline $\begin{array}{l}\text { AlV } \\
\text { intensification }\end{array}$ & $\begin{array}{l}0.0117 \\
(0.1720)\end{array}$ & $\begin{array}{l}-0.1581 \\
(0.1633)\end{array}$ & $\begin{array}{l}-0.0608 \\
(0.1724)\end{array}$ & $\begin{array}{l}0.1468 \\
(0.1538)\end{array}$ & $\begin{array}{l}0.0055 \\
(0.0434)\end{array}$ & $\begin{array}{l}-0.0562 \\
(0.0502)\end{array}$ & $\begin{array}{l}-0.0121 \\
(0.0444)\end{array}$ & $\begin{array}{l}0.0506 \\
(0.0526)\end{array}$ \\
\hline Fertile soil & $\begin{array}{l}0.2603^{* * *} \\
(0.0926)\end{array}$ & $\begin{array}{l}0.0132 \\
(0.0821)\end{array}$ & $\begin{array}{l}-0.0484 \\
(0.0885)\end{array}$ & $\begin{array}{l}-0.1006 \\
(0.0791)\end{array}$ & $\begin{array}{l}0.0608^{* * *} \\
(0.0225)\end{array}$ & $\begin{array}{l}0.0020 \\
(0.0261)\end{array}$ & $\begin{array}{l}-0.0141 \\
(0.0230)\end{array}$ & $\begin{array}{l}-0.0341 \\
(0.0273)\end{array}$ \\
\hline $\begin{array}{l}\text { Distance to } \\
\text { watering point }\end{array}$ & $\begin{array}{l}-0.0126 \\
(0.0346)\end{array}$ & $\begin{array}{l}-0.0069 \\
(0.0174)\end{array}$ & $\begin{array}{l}-0.0041 \\
(0.0206)\end{array}$ & $\begin{array}{l}-0.0612 \\
(0.0543)\end{array}$ & $\begin{array}{l}-0.0017 \\
(0.0051)\end{array}$ & $\begin{array}{l}-0.0026 \\
(0.0059)\end{array}$ & $\begin{array}{l}-0.0014 \\
(0.0052)\end{array}$ & $\begin{array}{l}-0.0103^{*} \\
(0.0062)\end{array}$ \\
\hline $\begin{array}{l}\text { Distance to } \\
\text { market }\end{array}$ & $\begin{array}{l}-0.0083 \\
(0.0177)\end{array}$ & $\begin{array}{l}0.0289^{*} \\
(0.0164)\end{array}$ & $\begin{array}{l}0.0039 \\
(0.0177)\end{array}$ & $\begin{array}{l}0.0107 \\
(0.0159)\end{array}$ & $\begin{array}{l}-0.0023 \\
(0.0044)\end{array}$ & $\begin{array}{l}0.0088^{*} \\
(0.0051)\end{array}$ & $\begin{array}{l}0.0013 \\
(0.0045)\end{array}$ & $\begin{array}{l}0.0035 \\
(0.0054)\end{array}$ \\
\hline $\begin{array}{l}\text { Type of } \\
\text { irrigation } \\
\text { system }\end{array}$ & $\begin{array}{l}0.4205^{* * *} \\
(0.1211)\end{array}$ & $\begin{array}{l}0.2688^{* *} \\
(0.1317)\end{array}$ & $\begin{array}{l}-0.0732 \\
(0.1274)\end{array}$ & $\begin{array}{l}0.4670^{* * *} \\
(0.1160)\end{array}$ & $\begin{array}{l}0.1327^{* * *} \\
(0.0333)\end{array}$ & $\begin{array}{l}0.0625 \\
(0.0385)\end{array}$ & $\begin{array}{l}-0.0171 \\
(0.0340)\end{array}$ & $\begin{array}{l}0.1634^{* * *} \\
(0.0403)\end{array}$ \\
\hline TLU & $\begin{array}{l}0.1167 \\
(0.0769)\end{array}$ & $\begin{array}{l}0.1216^{*} \\
(0.0719)\end{array}$ & $\begin{array}{l}0.1883^{* *} \\
(0.0768)\end{array}$ & $\begin{array}{l}0.0720 \\
(0.0690)\end{array}$ & $\begin{array}{l}0.0271 \\
(0.0194)\end{array}$ & $\begin{array}{l}0.0352 \\
(0.0224)\end{array}$ & $\begin{array}{l}0.0474^{* *} \\
(0.0200)\end{array}$ & $\begin{array}{l}0.0250 \\
(0.0235)\end{array}$ \\
\hline $\begin{array}{l}\text { Number of } \\
\text { farm } \\
\text { enterprises }\end{array}$ & $\begin{array}{l}0.0811^{* * *} \\
(0.0208)\end{array}$ & $\begin{array}{l}0.0075 \\
(0.0195)\end{array}$ & $\begin{array}{l}0.0120 \\
(0.0210)\end{array}$ & $\begin{array}{l}0.0393^{* *} \\
(0.0189)\end{array}$ & $\begin{array}{l}0.0803^{* * *} \\
(0.0211)\end{array}$ & $\begin{array}{l}0.0024 \\
(0.0061)\end{array}$ & $\begin{array}{l}0.0021 \\
(0.0054)\end{array}$ & $\begin{array}{l}0.0135^{* *} \\
(0.0064)\end{array}$ \\
\hline $\begin{array}{l}\text { Off-farm } \\
\text { income }\end{array}$ & $\begin{array}{l}-0.1186 \\
(0.1029)\end{array}$ & $\begin{array}{l}-0.1224 \\
(0.0981)\end{array}$ & $\begin{array}{l}0.1453 \\
(0.0981)\end{array}$ & $\begin{array}{l}0.1036 \\
(0.0913)\end{array}$ & $\begin{array}{l}-0.0312 \\
(0.0259)\end{array}$ & $\begin{array}{l}-0.0345 \\
(0.0300)\end{array}$ & $\begin{array}{l}0.0407 \\
(0.0265)\end{array}$ & $\begin{array}{l}0.0324 \\
(0.0314)\end{array}$ \\
\hline $\begin{array}{l}\text { Access to } \\
\text { information }\end{array}$ & $\begin{array}{l}-0.2531^{* *} \\
(0.0999)\end{array}$ & $\begin{array}{l}0.0913 \\
(0.0901)\end{array}$ & $\begin{array}{l}0.1394^{*} \\
(0.0942)\end{array}$ & $\begin{array}{l}0.3440^{* * *} \\
(0.0843)\end{array}$ & $\begin{array}{l}-0.0610^{* * *} \\
(0.0243)\end{array}$ & $\begin{array}{l}0.0312 \\
(0.0281)\end{array}$ & $\begin{array}{l}0.0387 \\
(0.0248)\end{array}$ & $\begin{array}{l}0.1173^{* * *} \\
(0.0295)\end{array}$ \\
\hline $\begin{array}{l}\text { Access to } \\
\text { warning on } \\
\text { shocks }\end{array}$ & $\begin{array}{l}-0.0503 \\
(0.1233)\end{array}$ & $\begin{array}{l}0.0606 \\
(0.1069)\end{array}$ & $\begin{array}{l}0.0482 \\
(0.1165)\end{array}$ & $\begin{array}{l}0.3039^{* * *} \\
(0.1028)\end{array}$ & $\begin{array}{l}-0.0067 \\
(0.0298)\end{array}$ & $\begin{array}{l}0.0194 \\
(0.0223)\end{array}$ & $\begin{array}{l}0.0168 \\
(0.0304)\end{array}$ & $\begin{array}{l}0.1072^{* * *} \\
(0.0361)\end{array}$ \\
\hline $\begin{array}{l}\text { Contract } \\
\text { farming }\end{array}$ & $\begin{array}{l}0.0932 \\
(0.1629)\end{array}$ & $\begin{array}{l}0.0558 \\
(0.1496)\end{array}$ & $\begin{array}{l}0.2045 \\
(0.1527)\end{array}$ & $\begin{array}{l}0.3189^{* *} \\
(0.1417)\end{array}$ & $\begin{array}{l}0.0237 \\
(0.0411)\end{array}$ & $\begin{array}{l}0.0406 \\
(0.0476)\end{array}$ & $\begin{array}{l}0.0584 \\
(0.0421)\end{array}$ & $\begin{array}{l}0.1117^{* * *} \\
(0.0499)\end{array}$ \\
\hline Certification & $\begin{array}{l}0.0578 \\
(0.0997)\end{array}$ & $\begin{array}{l}0.3972^{* * *} \\
(0.0877)\end{array}$ & $\begin{array}{l}0.1591^{*} \\
(0.0944)\end{array}$ & $\begin{array}{l}0.4392^{* * *} \\
(0.0844)\end{array}$ & $\begin{array}{l}0.0157 \\
(0.0247)\end{array}$ & $\begin{array}{l}0.1338^{* * *} \\
(0.0286)\end{array}$ & $\begin{array}{l}0.0449^{*} \\
(0.0253)\end{array}$ & $\begin{array}{l}0.1601^{* * *} \\
(0.0299)\end{array}$ \\
\hline Constant & $\begin{array}{l}-1.0986^{* * *} \\
(0.3317)\end{array}$ & $\begin{array}{l}-1.9073^{* * *} \\
(0.3157)\end{array}$ & $\begin{array}{l}-1.4601^{* * *} \\
(0.3232)\end{array}$ & $\begin{array}{l}-1.7972^{* * *} \\
(0.2995)\end{array}$ & $\begin{array}{l}-0.1911^{* *} \\
(0.0817)\end{array}$ & $\begin{array}{l}-0.0530^{* * *} \\
(0.0946)\end{array}$ & $\begin{array}{l}-0.0625 \\
(0.0836)\end{array}$ & $\begin{array}{l}-0.1145 \\
(0.0991)\end{array}$ \\
\hline
\end{tabular}

Likelihood ratio test of: $r$ rho2 $1=$ rho31 $=$ rho4 $1=$ rho32 $=$ rho42 $=r$ ho43 $=0 ; X^{2}(6)=14.931$ Prob $>X^{2}=0.020$

Figures in parentheses are robust standard errors

${ }^{*} p<0.1 ;{ }^{* *} p<0.05 ;{ }^{* * *} p<0.01$

products, and only sell these products at the right time without loss of quality. Furthermore, this group of farmers would also seek credit financial services in order to acquire the necessary equipment and/or technologies, such as irrigation systems for high-quality 
and sustainable production, and hence, it offers an integral solution for overcoming the main constraints faced when accessing HVMCs. In contrast, access to market information (prices) was found to have negative effects on access to HVM competitiveness pillars. This is surprising and is largely attributed to the price of required standards, equipment, transportation facilities and other requirements from HVMCs which could carry a high initial cost that the majority of poor smallholder farmers are unable to pay before supplying the HVMCs. Moreover, this could also be attributed to the source of such information, which is consistent with the findings of Ouma et al. (2010) who point out that market price information acquired through neighbours reduces the probability of market participation among smallholder banana farmers in Central Africa.

Furthermore, Bellemare (2012) indicated that households who have access to market price information may end up creating strong linkages with buyers along agricultural commodity chains through contract farming and thus improve their access to HVMCs. In this regard, access to contract farming was also found to be an important determinant in accessing the EXT competitiveness pillar. This implies that smallholder AIV farmers who are contracted by suppliers are more likely to have access to the EXT competitiveness pillar. Depending on the contractual arrangements and the type of market that the produce is supplied to, as well as the nature of the products, smallholder AIV farmers who are in any form of contract farming have better pricing terms with good quality products that can be accepted in HVMCs. HVMCs require formal contracts and are predominantly found in accessible areas, resulting in higher welfare gains for smallholder farmers under contract (Barrett et al. 2012; Ma and Abdulai 2016).

Access to information related to warnings of future unexpected events/shocks is positively related to access to the EXT competitiveness pillar. This implies that smallholder farmers who receive warnings are more likely to access the EXT competitiveness pillar. Therefore, access to a considerable amount of information on future events enables smallholder farmers to effectively learn about the use of ex ante coping strategies on their farmland, while maintaining food safety standards, and build up their household assets for future consumption as well as supply HVMCs during adverse periods/occurrence of shocks (Narrod et al. 2009; Tran 2015). The reason is that when households are aware of incipient unfavourable events, they tend to take necessary mitigation measures, for instance building up household assets (as an ex-ante coping strategy), which will lessen the impacts of such events. These results also suggest that certification is an important factor in informing the decision taken by smallholder AIV farmers to access three pillars of competitiveness in HVMCs. Households who have access and are certified farmers are more likely to gain access to the GRP, CRD and EXT competitiveness pillars. This is largely attributed to the fact that certification comes at a cost of around $30 \%$ of a Kenyan smallholder's annual vegetable income (Asfaw et al. 2010). Providers also always prefer to work with farmers who are in groups because of ease in terms of the required quantities levels, efficiency and effectiveness in the management of the operation, as well as access to other relevant services such as credit (Chiputwa et al. 2015).

In general, smallholder farmers who are certified had greater access to the pillars of competitiveness in HVMCs because of greater productivity, standards and bargaining power, which can give them access to secure/direct and strong linkages with buyers and hence boost household income. Financial capital variables were also important in 
determining their decision to seek access to pillars of competitiveness in HVMCs. With regard to total livestock units (TLU), smallholder AIV farmers with a higher TLU were found to be more likely to seek the GRP and CRD competitiveness pillars. This implies that the higher the TLU, the greater the probability of a smallholder AIV farmer becoming a member of a farmers' group as well as accessing credit services. Furthermore, smallholder AIV farmers may be borrowing from informal sources (farmers' groups) against the assets (livestock) they own or sometimes against future expected incomes, using livestock assets as collateral, especially when options are limited. These findings are consistent with those of Bahta and Malope (2014), who argue that smallholder households with higher TLU have higher gross margins and are competitive in HVMCs because they are more likely to use secured loans and divestment strategies. The number of farm enterprises that households operate is an important factor in informing the decision to access the HVM and EXT competitiveness pillars. Consistent with McCord et al. (2015), smallholder AIV farmers who have a greater number of farm enterprises were found to be more likely to access extension services. Having more farm enterprises requires technical knowledge of farming techniques in terms of assets and resource allocations, cultural practices, management and response to shocks such as pests and diseases, as well as entrepreneurial skills, all of which are acquired from extension agents, especially when supplying HVMCs.

Physical capital variables are important factors influencing access to pillars of competitiveness in HVMCs. The results indicated that the type of irrigation system used by smallholder AIV farmers was an important determinant of the choice of pillars of competitiveness in HVMC such as EXT, GRP and HVM. This suggests that farmers who use modern irrigation systems are more likely to have access to EXT, GRP and HVM. These results are consistent with the findings of Burney and Naylor (2012), who concluded that modern irrigation systems are capital-intensive infrastructures that are important in determining smallholders' decisions to switch to high-value crops and hence access HVMs. In addition, the positive relationship between the use of modern irrigation systems and HVM access is consistent with the findings of Ngenoh et al. (2015), who found that the use of modern production systems are expected to increase the yields of most irrigated products. Use of modern irrigation systems enables smallholder farmers to become competitive in rapidly changing environments and hence require efficient information flows. This is only possible if smallholder farmers use social networks through their membership of farmers' groups and have access to extension services in order to understand the technical and entrepreneurial skills required.

Distance to the nearest market was found to be positively related to access to the GRP competitiveness pillar. These results are consistent with those of Narrod et al. (2009) and Trebbin (2014), who noted that smallholder farmers who are located at a great distance from input and output markets are more likely to have access to farmers' groups in order to benefit from economies of scale, especially when procuring inputs and supplying farm products to HVMCs. In addition, access to HVMCs requires smallholder farmers to meet certain quantity and quality standards in terms of demand and consumer preferences, such as different quantities for different products. These processes are closely monitored, and for smallholder farmers to participate in these value-adding processes (grading, processing and packing standards) and possibly increase their bargaining power, they have to work in groups, which also reduces the cost 
of accessing HVMCs. This is because the distance either to input or output markets plays a vital role in determining the farmers' decision-making process in various ways. Moreover, Wollni and Zeller (2007) noted that smallholder farmers with better access to farmer groups, coupled with the availability of information and support services as well as the opportunity costs of labour, stand a better chance of minimising high input price volatilities by procuring inputs in bulk.

Natural capitals are important factors that influence the decision to access pillars of competitiveness in HVMCs. The location of smallholder farms is a major determinant in accessing HVMC pillars of competitiveness. Smallholder farmers from rural areas are more likely to access GRP and EXT, while their counterparts in peri-urban areas are more likely to access HVM and CRD. This implies that rural farmers are faced with credit and high-value market access constraints because they lack the necessary institutions and infrastructure more than their peri-urban counterparts do. This result is consistent with the findings of Markelova and Mwangi (2010) and Fischer and Qaim (2012), who noted that poor infrastructure, a lack of supporting institutions, high transaction costs and limited market opportunities in rural and remote areas lead to highly inefficient and long supply chains that are dominated by non-value-adding intermediaries. In addition, farmers who collectively market their farm products are more likely to benefit from high-value supply chains than from local markets. Furthermore, the results indicated that peri-urban farmers are disadvantaged in terms of accessing EXT and GRP because there is a wide variation in what they are doing on their farms, and hence, they find it difficult to come together in groups. In turn, this also makes it difficult for the extension agents to arrange dissemination strategies such as field days, field demonstrations and workshops.

Access to agricultural land with fertile soil ${ }^{6}$ is an important factor when smallholder farmers are accessing the HVM competitiveness pillar. Consistent with Ferris et al. (2014) and Schindler et al. (2016), smallholder AIV farmers who have land with fertile soil were found to be more likely to have access to HVM because they use fewer production inputs to produce significant quantities of high-quality products that are accepted in HVMCs. In addition, these farmers may utilise the resources that would have been used to purchase fertility-enhancing inputs such as fertilisers to meet other relevant requirements, which specifically improve their access to the HVM competitiveness pillar.

Human capital variables play a key role in accessing pillars of competitiveness in HVMC. For instance, the education level of the household head among smallholder AIV farmers was shown to be significant, with a positive relationship with access to the CRD and EXT competitiveness pillars at household level. In line with Rao et al. (2012), better-educated farmers are more likely to be willing to seek extension services because they are able to process the often abstract extension packages and convert such information into practice, making them more likely to participate in HVMCs. In addition, HVMCs require specific standards to be met, and educated farmers are better able to synthesise such information and easily adjust to new or modern production techniques and market requirements. These modern production techniques and other demands made by HVMCs require higher capital investments, which ultimately calls for access to credit services by smallholder farmers. According to Kiplimo et al. (2015), access to credit services is also easier for smallholder farmers with a higher level of education 
since they participate in better off-farm activities that can be used as collateral while accessing these services. With regard to household size, and in agreement with Jaimovich (2015), smallholder households with more members were found to be more likely to access the CRD competitiveness pillar. This suggests that the larger the household, the greater the demand for food and other resources, and hence, the greater the need for external links to several networks that can provide the necessary services, such as credit. The reason for this is that such households are endowed with labour and only constrained by the resources needed to utilise the available family labour.

\section{Conclusions}

This paper determined the main factors influencing the decisions of smallholder AIV farmers to access pillars of competitiveness in HVMCs in Kenya. The pillars of competitiveness (HVM, CRD, GRP and EXT) are the necessary pre-conditioning factors that enable smallholder AIV farmers to overcome the major constraints limiting their competitiveness in HVMCs. Using a detailed household-level data and a multivariate probit model, more than two thirds of the interviewed farmers were found to have access to at least one pillar of competitiveness in HVMCs. Furthermore, the majority of these farmers were from rural areas and had access to EXT and GRP, while their peri-urban counterparts had mainly accessed the CRD and HVM pillars of competitiveness. This implies that smallholder AIV farmers face numerous constraints in accessing competitiveness pillars, and therefore, efforts need to be made to improve their level of access to these pillars of competitiveness so that they can participate effectively and efficiently in HVMCs. The results of the model estimations identified that smallholders' decisions to cope with both production and marketing shocks (PMS) were a major factor informing their decision to access the CRD and EXT competitiveness pillars. Coping with PMS enables farmers to access HVMCs and thus build on their assets and invest in capital-intensive production and marketing technologies, which also help them develop their ability to withstand shocks and stresses. Furthermore, this study identified that access to information on market prices and warnings and to critical services such as contract farming, certification, grading and irrigation technologies was the most important factor in smallholder AIV farmers' decisions to access HVMC competitiveness pillars. Future studies should evaluate whether smallholder farmers' access to quality information, as well as its source, plays a critical role in conditioning access to pillars of competiveness.

These results have significant policy implications. It is important to design policies that are well-founded, providing the necessary information on the best possible ways of overcoming the constraints faced by smallholder farmers when attempting to access pillars of competitiveness in HVMCs. There is also a need to establish and promote mobile phone-based platforms to enable smallholder farmers to easily access real-time information and banking services, especially in remote rural areas where formal financial services are limited. These specific policies will go a long way towards improving smallholder AIV farmers' access to pillars of competitiveness by enabling them to overcome information and resource constraints. Furthermore, access to the price information, institutions and relevant resources would lead to an increase in the number of smallholder farmers accessing pillars of competitiveness. This will ultimately lead to better access to production technologies, which will further result in increased 
production of high-quality products, and thus enable smallholder farmers to supply HVMCs successfully and consistently. Finally, the importance of accessing contract farming and certification in smallholder farmers' decisions to access pillars of competitiveness suggests that there is a need for policies that support farmers securing direct supply contracts from HVMCs. This will allow them to directly shift to a market-oriented type of production and furthermore encourage them to diversify into farm enterprises offering high returns that will enable them to reduce the opportunity costs of on-farm labour and resource allocation, and thus reduce production costs in the long run.

\section{Endnotes}

${ }^{1}$ Competitiveness refers to the ability of smallholder farmers to sell products that meet market requirements in terms of price, quality and quantity while ensuring profitability over time, which enables them to prosper (Latruffe 2010).

${ }^{2}$ The term "high-value market chains" is used in this paper and in the literature to refer to non-traditional agricultural markets such as supermarkets, hospitals, schools, large hotels and restaurants that have higher product prices because of their particular requirements, including high quality standards, handling, packaging and other regulations (Fernandez-Stark et al. 2012).

${ }^{3}$ The four pillars are access to HVMCs, training/extension, finance/credit and farmers' groups/horizontal and vertical coordination and collaboration.

${ }^{4}$ These pillars are access to high-value markets (HVM), farmers' groups (GRP), credit services (CRD) and extension services (EXT).

${ }^{5}$ For more information on the "four key pillars" of the holistic model, see Fernandez-Stark et al. (2012).

${ }^{6}$ Soil fertility was measured using farmers' perception of their soil fertility of their land parcels on which AIVs have been grown in the past 12 months, with the options of unfertile, somewhat fertile, moderately fertile and very fertile. In this study, unfertile and somewhat fertile were used to represent unfertile lands, while moderately fertile and very fertile represent fertile land.

\footnotetext{
Abbreviations

AIV: African indigenous vegetables; APP: Asset-processes-performance; CRD: Credit services; EXT: Extension services; FAO: Food and Agriculture Organization; GRP: Farmers' groups; HCDA: Horticultural Crops Development Authority; HORTINLEA: Horticultural Innovation and Learning for Improved Nutrition and Livelihood in East Africa; HVM: Highvalue markets; HVMC: High-value market chains; MVP: Multivariate probit; PMS: Production and marketing shocks; SME: Small and medium-sized enterprises; SSA: Sub-Saharan Africa; TLU: Total livestock units
}

\section{Acknowledgements}

The authors are very grateful for all the support given to the study by the Horticultural Innovation and Learning for Improved Nutrition and Livelihood in East Africa (HORTINLEA) project, whose data was used in the analysis. We would also like to thank the team who played a role in the project design, survey, data entry and analysis for their efforts.

Funding

Not applicable

Availability of data and materials

The data for this study was drawn from the larger HORTINLEA project survey data, and the authors do not have the permission to share the data. 
survey, data entry, data cleaning, data analysis, and write-up of the first draft. All the authors oversaw the interpretation and discussion of the results. Finally, all the authors have read and approved the final manuscript for submission.

\section{Competing interests}

The authors have declared that they have no competing interests and thus, on behave of all the authors, I would like to state categorically that we have no conflict of interest whatsoever concerning this article. Finally, we wish to state that we are entirely responsible for any errors of omission or commission.

\section{Publisher's Note}

Springer Nature remains neutral with regard to jurisdictional claims in published maps and institutional affiliations.

\section{Author details}

${ }^{1}$ Department of Agricultural Economics, Humboldt University of Berlin, Invalidenstr. 42, 10115 Berlin, Germany. ${ }^{2}$ Institute of Arid Lands Management, Laikipia University, P.O. Box 1100, Nyahururu 20300, Kenya. ${ }^{3}$ Department of Agricultural Economics and Agribusiness Management, Egerton University, P.O. Box 536, Egerton 20115, Kenya.

Received: 23 January 2018 Accepted: 10 January 2019

Published online: 30 January 2019

References

Ajitabh A, Momaya KS (2004) Competitiveness of firms: review of theory, frameworks and models. Singap Manag Rev 26(1): 45-61

Asfaw S, Mithöfer D, Waibel H (2010) What impact are EU supermarket standards having on developing countries' export of high-value horticultural products? Evidence from Kenya. J Int Food Agribusiness Mark 22(3-4):252-276

Bahta S, Malope P (2014) Measurement of competitiveness in smallholder livestock systems and emerging policy advocacy: an application to Botswana. Food Policy 49:408-417. https://doi.org/10.1016/j.foodpol.2014.10.006

Barrett CB (2008) Smallholder market participation: concepts and evidence from Eastern and Southern Africa. Food Policy 33(4):299-317

Barrett CB, Bachke ME, Bellemare MF, Michelson HC, Narayanan S, Walker TF (2012) Smallholder participation in contract farming: comparative evidence from five countries. World Dev 40(4):715-730. https://doi.org/10.1016/j. worlddev.2011.09.006

Barrett CB, Reardon T, Webb P (2001) Nonfarm income diversification and household livelihood strategies in rural Africa: concepts, dynamics, and policy implications. Food Policy 26(4):315-331

Bellemare MF (2012) As you sow, so shall you reap: the welfare impacts of contract farming. World Dev 40(7):1418-1434. https://doi.org/10.1016/j.worlddev.2011.12.008

Boström M, Jönsson AM, Lockie S, Mol APJ, Oosterveer P (2015) Sustainable and responsible supply chain governance: challenges and opportunities. J Clean Prod 107:1-7. https://doi.org/10.1016/j.jclepro.2014.11.050

Buckley PJ, Pass CL, Prescott K (1992) The meaning of competitiveness. Servicing International Markets: Competitive Strategy of Firms

Burney JA, Naylor RL (2012) Smallholder irrigation as a poverty alleviation tool in sub-Saharan Africa. World Dev 40(1):110123. https://doi.org/10.1016/j.worlddev.2011.05.007

Chadha ML (2006) AVRDC's experiences within marketing of indigenous vegetables- a case study on commercialization of African Eggplant

Chege PM, Kuria EN, Kimiywe JO, Nyambaka HN (2014) Changes in nutrient content for $\beta$-carotene, iron and zinc in solar dried and stored Amaranthus cruentus vegetables. Int J Agric Innov Res 3(3):880-882

Chelang'a P, Obare G, Kimenju S (2013) Analysis of urban consumers' willingness to pay a premium for African Leafy Vegetables (AIVs) in Kenya: a case of Eldoret Town. Food Sec 5(4):591-595

Chiputwa B, Spielman DJ, Qaim M (2015) Food standards, certification, and poverty among coffee farmers in Uganda. World Dev 66:400-412. https://doi.org/10.1016/j.worlddev.2014.09.006

FAO (2014) The state of food insecurity in the world 2014: strengthening the enabling environment for food security and nutrition. Food and Agriculture Organization of the United Nations, Rome. Available at: http://www.fao.org/publications/ sofi/2014/en/

Fernandez-Stark K, Bamber P, Gereffi G (2012) Inclusion of Small-And Medium-Sized Producers in High-Value Agro-Food Value Chains. Center on Globalization, Governance and Competitiveness, Duke University, 38

Ferris S, Robbins P, Best R, Seville D, Buxton A, Shriver J, Wei E (2014) Linking smallholder farmers to markets and the implications for extension and advisory services. MEAS Brief 4(10):13-14

Fischer E, Qaim M (2012) Linking smallholders to markets: determinants and impacts of farmer collective action in Kenya. World Dev 40(6):1255-1268. https://doi.org/10.1016/j.worlddev.2011.11.018

Franken JRV, Pennings JME, Garcia P (2014) Measuring the effect of risk attitude on marketing behaviour. Agric Econ 45(5): 525-535. https://doi.org/10.1111/agec.12104

Frankenberger D, Swallow K, Mueller M, Spangler T, Downen J, Alexander S (2013) Feed the future learning agenda literature review: improving resilience of vulnerable populations. USAID, Washington DC

Government of Kenya (GoK) (2012) Kenya National Bureau of Statistics (KNBS). Economic survey report 2012. Government printers. Nairobi

von Grebmer K, Bernstein J, Nabarro D, Prasai N, Amin S, Yohannes Y, Sonntag A, Patterson F (2016) The concept of the global hunger index. IFPRI book chapters, 6-9

Gruère G, Nagarajan L, King EDIO (2009) The role of collective action in the marketing of underutilized plant species: lessons from a case study on minor millets in South India. Food Policy 34(1):39-45. https://doi.org/10.1016/j.foodpol.2008.10.006 
HCDA. (2014). National horticulture validated report. Kenya, Ministry of Agriculture, Department of Horticultural Crops Development Authority. Kenyan Government printer. Retrieved from http://www.agricultureauthority.go.ke/wp-content/ uploads/2016/05/Horticulture-Validated-Report-2014-Final-copy.pdf

Jahnke HE (1982) Livestock production systems and livestock development in tropical Africa (253p). Kieler Wissenschaftsverlag, Kiel

Jaimovich D (2015) Missing links, missing markets: evidence of the transformation process in the economic networks of Gambian villages. World Dev 66:645-664. https://doi.org/10.1016/j.worlddev.2014.09.019

Kimiywe J, Waudo J, Mbithe D, Maundu P (2007) Utilization and medicinal value of indigenous leafy vegetables consumed in urban and peri-urban Nairobi. Afr J Food Agric Nutr Dev 7(4):1-15

Kiplimo JC, Ngenoh E, Koech W, Bett JK (2015) Determinants of access to credit financial services by smallholder farmers in Kenya. J Dev Agric Econ 7(9):303-313. https://doi.org/10.5897/JDAE2014.0591

Latruffe $L$ (2010) Competitiveness, productivity and efficiency in the agricultural and agri-food sectors. OECD Food, Agriculture and Fisheries Papers, No. 30, OECD Publishing, Paris. https://doi.org/10.1787/5km91nkdt6d6-en

Ma W, Abdulai A (2016) Linking apple farmers to markets: determinants and impacts of marketing contracts in China. China Agric Econ Review 8(1):2-21

Maddala GS (1986) Limited-dependent and qualitative variables in econometrics (No. 3). Cambridge University Press

Mampholo BM, Sivakumar D, Thompson AK (2016) Maintaining overall quality of fresh traditional leafy vegetables of Southern Africa during the postharvest chain. Food Rev Intl 32(4):400-416

Man TW, Lau T, Chan KF (2002) The competitiveness of small and medium enterprises: a conceptualization with focus on entrepreneurial competencies. J Bus Ventur 17(2):123-142

Markelova H, Meinzen-Dick R, Hellin J, Dohrn S (2009) Collective action for smallholder market access. Food Policy 34(1):1-7. https://doi.org/10.1016/j.foodpol.2008.10.001

Markelova H, Mwangi E (2010) Collective action for smallholder market access: evidence and implications for Africa. Rev Policy Res 27(5):621-640

McCord PF, Cox M, Schmitt-Harsh M, Evans T (2015) Crop diversification as a smallholder livelihood strategy within semi-arid agricultural systems near Mount Kenya. Land Use Policy 42:738-750. https://doi.org/10.1016/j.landusepol.2014.10.012

Muhanji G, Roothaer RL, Webo C, Stanley M (2011) African indigenous vegetable enterprises and market access for smallscale farmers in East Africa. Int J Agric Sustain 9(1):194-202

Narrod C, Roy D, Okello J, Avendaño B, Rich K, Thorat A (2009) Public-private partnerships and collective action in high value fruit and vegetable supply chains. Food Policy 34(1):8-15. https://doi.org/10.1016/j.foodpol.2008.10.005

Ngenoh E, Kebede SW, Bett HK, Bokelmann W (2016) Role of high-value market participation on poverty reduction among African leafy vegetable farmers in Kenya. Afr J Hortic Sci 10:14-20

Ngenoh E, Kirui LK, Mutai BK, Maina MC, Koech W (2015) Economic determinants of the performance of public irrigation schemes in Kenya. J Dev Agric Econ 7(10):344-352

Ngugi IK, Gitau R, Nyoro J (2007) Access to high value markets by smallholder farmers of African indigenous vegetables in Kenya. Regoverning Markets Innovative Practice Series, IIED, London

Olwande J, Smale M, Mathenge MK, Place F, Mithöfer D (2015) Agricultural marketing by smallholders in Kenya: a comparison of maize, kale and dairy. Food Policy 52:22-32

Omiti J, Otieno D, Nyanamba T, McCullough E (2009) Factors influencing the intensity of market participation by smallholder farmers: a case study of rural and peri-urban areas of Kenya. Afr J Agric Resour Econ 3(1):57-82

Omiti JM (2012) Research challenges in agriculture and rural development in Kenya. Afr J Food Agric Nutr Dev 12(6):1-5

Ouma E, Jagwe J, Obare GA, Abele S (2010) Determinants of smallholder farmers' participation in banana markets in Central Africa: the role of transaction costs. Agric Econ 41(2):111-122. https://doi.org/10.1111/j.1574-0862.2009.00429.x

Rao EJ, Brümmer B, Qaim M (2012) Farmer participation in supermarket channels, production technology, and efficiency: the case of vegetables in Kenya. Am J Agric Econ 94(4):891-912

Reardon T, Barrett CB, Berdegué JA, Swinnen JF (2009) Agrifood industry transformation and small farmers in developing countries. World Dev 37(11):1717-1727

Rios AR, Masters WA, Shively GF (2008) Linkages between market participation and productivity: results from a multi-country farm household sample. Paper presented at the American Agricultural Economics Association Annual Meeting, Orlando, Florida, USA, July 27-19, 2008

Schindler J, Graef F, König H, McHau D, Saidia P, Sieber S (2016) Sustainability impact assessment to improve food security of smallholders in Tanzania. Environ Impact Assess Rev 60:52-63. https://doi.org/10.1016/j.eiar.2016.04.006

Torero M (2011) A framework for linking small farmers to markets. In: IFAD Conference on New Directions for Smallholder Agriculture, vol 24, p 25

Tran VQ (2015) Household's coping strategies and recoveries from shocks in Vietnam. Q Rev Econ Finance 56:15-29. https:// doi.org/10.1016/j.gref.2014.06.006

Trebbin A (2014) Linking small farmers to modern retail through producer organizations - experiences with producer companies in India. Food Policy 45:35-44. https://doi.org/10.1016/j.foodpol.2013.12.007

Wollni M, Zeller M (2007) Do farmers benefit from participating in specialty markets and cooperatives? The case of coffee marketing in Costa Rica1. Agric Econ 37(2-3):243-248

Wooldridge JM, (2010) Econometric analysis of cross section and panel data: MIT press

Xinshen D, Hazell P, Resnick D, Thurlow J (2007) The role of agriculture in pro-poor growth in Sub-Saharan Africa. IFPRI, Washington DC

Zuwarimwe J, Mbaai S (2015) Factors influencing smallholder farmers' decisions to participate in livestock markets in Namibia. J Dev Agric Econ 7(7):254-261 